\title{
The adaptation of MAIN to Estonian
}

\author{
Reili Argus \\ Tallinn University
}

\section{Andra Kütt}

Tallinn University

This paper describes Estonian version of the Multilingual Assessment Instrument for Narratives (LITMUS-MAIN) to Estonian. A short description of Estonian, some challenges in the adapting MAIN to Estonian, the first experiences of using the Estonian MAIN and a summary of the first results are presented.

\section{Introduction}

This chapter briefly introduces the addition of Estonian to the existing language versions of the Language Impairment Testing in Multilingual Settings - Multilingual Assessment Instrument for Narratives (LITMUS-MAIN, hereafter MAIN; Gagarina et al., 2012, 2015, 2019). It describes the process of adapting MAIN to Estonian as well as how it has been used in research. So far, MAIN has mainly been adapted to Indo-European languages. Adding Estonian, a FinnoUgric language, which is significantly different typologically, will widen the empirical coverage of MAIN.

\section{A short description of the Estonian language}

Estonian, as a Finnic language of the Finno-Ugric language family, is a language with a rich morphology. It has a case system of 14 cases and verbs that are inflected for tense, number and person, but lacks an article system and grammatical gender (Erelt, 2007). With regard to morphological typology, Estonian exhibits both agglutinative and fusional features. Phonological changes in stems are principally of two kinds: gradation changes (affecting the root and medial sounds) and other changes (omission, addition and ordering changes of final phonemes). When the stem is subject to gradation it will occur in strong or weak forms in 
different grades (Erelt et al., 1995, p. 130), e.g. vatti 'cottonwool.PARTIT' and vati 'cottonwool.GEN'. There are more postpositions than prepositions in Estonian and several spatial relations can be expressed both with case forms and spatial postpositions, e.g. lauale 'table.ALLAT' or laua peale 'table.GEN onto' for 'onto the table'.

The Estonian verbal agreement morphology (person and number) allows for both subject and object ellipsis and therefore the reference to a person or an object can be expressed only with a verb form consisting of a relevant suffix (e.g. läheb majja 'go.PRES.3SG house.ILL', i.e. 'she/he goes into the house'). The Estonian word order is statistically characterized mainly by the V2 principle (Tael, 1988, p. 40), i.e. that the verb usually comes second in the clause, and Estonian is most often considered an SVO language (Ehala, 2006, p. 49). Although the neutral word order of a standard sentence is SVX in main clauses, SVX and XVS are equally frequent (Lindström 2000). At the same time, in marked sentence types (possessor and experiencer constructions, existential sentences, resultative sentences) the Estonian word order can also be XSV and it has been argued that at the sentential level, the discourse configurational rules (the needs of organizing known and new information, e.g. usually placing new information into the end on the sentence) are more important than the grammatical principles (e.g. V2) of ordering constituents and several other word order patterns (e.g. OSV, VSX) are also possible in Estonian (Ehala, 2006, p. 84).

Thus, Estonian has several typological features that are different from most IndoEuropean languages. Even compared to the closely related language Finnish, Estonian has some special features, e.g. the inflectional morphology in Estonian is more fusional and not as regular as in Finnish. Therefore, the use of MAIN an empirical basis for comparisons between not only typologically different languages as Finno-Ugric and Indo-European languages, but also for closely related language like Estonian and Finnish.

There are approximately 1.08 million native speakers of Estonian. The majority of them, 883,707 speakers, lives in the Republic of Estonia, ${ }^{2}$ where Estonian is the official language. Outside of Estonia, there are roughly 160,000 native Estonian speakers, found primarily in Finland, Russia, the USA, Canada, and Sweden. There are also 170,000 speakers of Estonian as a second language (Erelt, 2003, p. 7; Kilgi, 2012, PHC, 2011). Russian-speaking people form the biggest minority language group in Estonia. At the same time, this group is quite heterogeneous: among the speakers of Russian, there are so called old-settlers and $2^{\text {nd }}-3^{\text {rd }}$ generation immigrants and their descendants as well recent immigrants; linguistically this group consists of Russian monolinguals, Estonian-Russian bilinguals, and people speaking Russian and some other language, e.g. Ukrainian. The majority of the younger generation of Russianspeaking people in Estonia nowadays speaks Russian, Estonian and English or some other foreign language.

The Estonian educational system is in the transition towards an educational system where Estonian is the primary language of instruction. Earlier, next to schools with Estonian as the language of instructions, there have also been schools with Russian as the sole language

\footnotetext{
${ }^{1}$ Illative is one of the locative cases with the basic meaning of 'into (the inside of)'.

${ }^{2}$ Data from 2016 (Blog of Statististics https://blog.stat.ee/2017/03/13/kui-palju-raagitakse-eestis-eesti-keelt/.)
} 
of instruction, but it is now compulsory in all schools to teach at least $60 \%$ of all subjects in Estonian. Therefore, the use of Estonian MAIN to evaluate narrative skills not only in monolingual but also in bilingual children might be useful.

\section{Adapting MAIN to Estonian}

An Estonian version of MAIN was created in 2012. The new revised Estonian MAIN, published as part of this issue was adapted from the revised English version (Gagarina et al., 2019), following the guidelines provided in Bohnacker \& Gagarina (2019).

In the first phase, Reili Argus, the first author of this paper, adapted the MAIN protocols to Estonian based on the 2012 version of the Estonian MAIN. The 2012 version had been piloted by the second author, Andra Kütt, a PhD-student in linguistics with 18 children. Additionally, several students of linguistics and speech-language pathology piloted it as well and suggested changes concerning the wording and word order in some stories. Finally, the authors revised the Estonian MAIN further based on the revised English version and incorporated the suggestions for minor language changes from the piloting.

The MAIN picture sequences and the story scripts did not require any cultural adaptations because the stories, characters and contexts were already suitable for children growing up in the Estonian context. The difficulties in the translation process concerned three issues: finding suitable translation equivalents for some adjectives and verbs, the sentence structure, and the usage of pronouns in Estonian.

With respect to the first issue, the most difficult adjectives to adapt were playful and cheerful. The first mentioned adjective was translated using a compound mänguhimuline 'lit. play.GEN-eagerness-adjectival suffix', which is not completely equivalent to the original adjective and is a somewhat long word, but is transparent in the structure and meaning of its components. It is also the most suitable word considering the sentence context. The adjective cheerful has at least two translation equivalents in Estonian, rõomsameelne 'cheerful, hearty' and rõ̃mus 'glad, happy, cheerful'. The word rõ̃mus was chosen as it was both more frequent and more appropriate for children. The verb to grab had to be translated differently in different contexts: in the context of a dog or a cat taking a fish or a sausage from the bucket, the verb näppama 'snatch, pilfer' was used, in other contexts, the verbs sikutama 'tug, pluck' or haarama 'grab, grasp' were used.

Concerning the second issue, the adaptation of the structure of the sentences, they did not cause any larger difficulties. Still, not all structural characteristics of the original sentences were retained. For example, the original sentence ... a cheerful boy was coming back from fishing with a bucket and a ball in his hands has the verb olema 'to be' in its Estonian translation (tal oli kott ühes ja ôhupall teises käes 'he had a bag in one and a balloon in other hand'). Some sentences were translated using a subordinate clause instead of a non-finite structure. For example, the sentence He looked at the dog chasing the mouse became Ta vaatas, kuidas koer hiirt taga ajab 'he looked, how the dog is chasing the mouse' and She was happy about the juicy worm for her babies was expressed as Ta oli onnelik selle mahlase ussikese üle, mis ta 
oma poegadele tõi 'She was happy for the juicy worm that she brought for her babies'. Although non-finite clauses are possible in Estonian and could have been used in all above mentioned examples, subordinate clauses were selected as more frequent in colloquial Estonian as well in child-directed speech.

As mentioned above, Estonian has no grammatical gender and the $3^{\text {rd }}$ person singular pronoun tema 'he/she' is used for both male and female referents. To avoid misunderstanding, in the second sentence in One day there was a mother goat who saw that her baby goat had fallen into the water and that it was scared. She jumped into the water... the personal pronoun she was substituted with the proper noun kitseema 'mother goat' in the translation (Kitseema hüppas vette 'mother goat jumped into the water'). Possessive pronouns are also used with lesser frequency in Estonian and, in some sentences, some of them were just omitted in the translation. For example, the sentence ...the boy began pulling his ball out of the water with his fishing rod. became ...hakkas poiss õngega oma palli veest välja tõmbama 'the boy began to pull out his (own) ball from the water with the fishing rod'.

\section{The use of MAIN in Estonian}

Until now, the Estonian MAIN (the story Baby Goat in the telling mode) has been used with 50 children (30 of them bilingual) and all these children's narratives have been added to the CHILDES Estonian MAIN database. ${ }^{3}$ However, only one study using the Estonian MAIN has been published (Kütt, 2018). Kütt (2018) reports the results from a pilot study using MAIN story Baby Goats in the telling mode with 18 monolingual Estonian children aged 4-8 years. Here, we give a brief summary of the results of this study.

With respect to the general procedure of the narrative tasks, Estonian children liked the pictures of MAIN and they also enjoyed telling the stories. Some children were not familiar with the term "to tell the story". Naming the characters of the story was not difficult for the children but many children asked who the characters in the pictures were or how to name them. Some children also added self-invented characters (e.g. a farmer) to the story.

However, the pilot study showed that certain aspects of the storytelling was quite difficult for Estonian children. For example, when producing a narrative, it was not natural for Estonian children to indicate a setting (time or place), but rather they began their stories with attempts and goals. Attempts and goals were also the most frequent components of children's stories. There was little complexity in the children's narratives and most children presented only goals or attempts but no outcomes. Least common was the production of all three macrostructural components (goal-attempt-outcome) within the same episode.

In the Estonian children's narratives, there were few words referring to a story characters' inner feelings or reactions. This results thus showed that Estonian children find it difficult to use emotion words, which is evidenced by their limited use of IST words (including

\footnotetext{
${ }^{3}$ See https://childes.talkbank.org/browser/index.php?url=Other/Estonian/MAIN/.
} 
emotion words) as well as their null-rated understanding of the internal reactions and states of individuals (Kütt, 2018, p. 104).

No connection was found between producing a more complex narrative and the child's narrative comprehension. The generally high scores on the MAIN comprehension questions demonstrate that the test stimulus, a series of pictures, were understood and that the test was generally appropriate for the children.

However, some links were found between the size of the vocabulary used in the narratives and the complexity of the story. The two children with the highest story structure scores had the richest vocabulary in their narratives and the child whose score was the lowest in the group used the smallest vocabulary.

To conclude, using MAIN for researching language acquisition can provide different insights into the acquisition of story-telling as well into several other more specific topics like the use of referential devices, different syntactic structures and the acquisition of lexicon, e.g. IST-words or adjectives. More data also needs to be collected from Estonian-Russian bilingual children. Such data would to contribute substantially to the research on early bilingual acquisition in an Estonian context; so far little such research has been carried out in Estonia.

\section{$5 \quad$ References}

Bohnacker, U. \& Gagarina, N. (2019). Background on MAIN - Revised, how to use it and adapt it to other languages. ZAS Papers in Linguistics, 63, iv-xii.

Ehala, M. (2006). The Word Order of Estonian: Implications to Universal Language. Journal of Universal Language, 7, 49-89.

Erelt, M. (2007). Estonian Language. In Mati Erelt (ed.) Linguistica Uralica, Supplementary Series, 1. Second edition (pp. 1-7). Tallinn: Estonian Academy Publishers.

Gagarina, N., Klop, D., Kunnari, S., Tantele, K., Välimaa, T., Balčiūnienė, I., Bohacker, U., \& Walters, J. (2012). MAIN: Multilingual Assessment Instrument for Narratives. ZAS Papers in Linguistics, 56.

Gagarina, N., Klop, D., Kunnari, S., Tantele, K., Välimaa, T., Balčiūnienė, I., Bohnacker, U., \& Walters, J. (2015). Assessment of Narrative Abilities in Bilingual Children. In S. Armon-Lotem, J. de Jong, \& N. Meir (Eds.), Assessing multilingual children: disentangling bilingualism from language impairment (pp. 243-269). Bristol: Multilingual Matters.

Gagarina, N., Klop, D., Kunnari, S., Tantele, K., Välimaa, T., Bohnacker, U. \& Walters, J. (2019). MAIN: Multilingual Assessment Instrument for Narratives - Revised. ZAS Papers in Linguistics, 63, 1-36.

Kilgi, A. (2012). Tõlkekeele dünaamika piibli esmaeestinduse käigus: verbi morfosüntaksi areng ja lõplik toimetamisfaas [Dynamics of translated language during the first translation of the Bible into Estonian: the development of morphosyntax of verb and the phase of final editing]. Doctoral dissertations of Tallinn University 27. Tallinn: Tallinna Ülikooli Kirjastus.

Kütt, A. (2018). MAIN-testi kasutamine eesti laste jutustamisoskuse hindamiseks. [Using the Multilingual Assessment Instrument for Narratives test for the assessment of Estonian children's narrative skills]. Eesti Rakenduslingvistika Ühingu aastaraamat, 14, 95-115.

Lindström, L. (2000). Narratiiv ja selle sõnajärg [Narrative and its word order]. Keel ja Kirjandus, 3, 190-200. 
PHC 2011 = PHC 2011: 157 native languages spoken in Estonia. (Population and Housing Census.) Accessed July 4, 2018. http://www.stat.ee/64629?parent_id=39113

Statistikablogi [Blog of Statististics]. Eesti Statistika. https://blog.stat.ee/2017/03/13/kui-palju-raagitakse-eestiseesti-keelt/ (Accessed 12 March 2020).

Tael, K. (1988). Sõnajärjemallid eesti keeles (võrrelduna soome keelega) [Estonian word order patterns compared with Finnish]. Tallinn: Eesti NSV Teaduste Akadeemia Keele ja Kirjanduse Instituut. Preprint KKI-56. 